\title{
Pedagogies for Inclusion in Finnish PE: The Teachers' Perspective
}

\author{
Christopher Mihajlovic \\ Faculty of Education, Institute for Sports Science and Motology, Philipps-Universität Marburg, Germany; Faculty \\ of Educational Sciences, Department of Teacher Education, University of Helsinki, Finland
}

\begin{abstract}
This paper analyses teachers' points of view regarding the changes and differentiations in their teaching content and didactic choices that they find necessary to ensure the participation of children with disabilities in physical education (PE) classes. The study consists of a qualitative approach that utilised semi-structured interviews, field notes and participant observation as data collection tools. Three subject teachers of PE, four special education teachers and one class teacher located in the Metropolitan area of Helsinki participated in the research. Given this small sample group, the results of the study make no claims for generalisability, but the findings could help other teachers share their perspectives and justify their educational choices. Findings revealed that the participants faced challenges when teaching in inclusive settings by making pedagogical modifications to ensure a learning environment suitable for all students. The findings from the research identified two main didactic approaches for including pupils with special needs in physical activities: The adaption of rules and equipment of traditional sports, and the implementation of suitable sports niches or specific games. The research also identified strategies for creating supportive learning environments and the importance of perceived teaching competence in adapted physical education (APE).
\end{abstract}

Keywords: inclusion, physical education, pedagogy, teaching competence

\section{Introduction}

Recently, the Finnish school system made the headlines again. It was reported that Finland would abolish all school subjects by 2020. The Finnish educational system has been considered by many countries as a shining example after it was the top overall performer among OECD countries in 2000 and 2003 PISA studies (Sahlberg, 2011). According to the latest social justice report among the EU member states in 2016 (Schraad-Tischler \& Schiller, 2016), Finland has done well to ensure that learning opportunities do not unfairly favour particular socioeconomic groups. The Finnish education policy aims to provide all citizens of Finland, regardless of their ethnic origin, gender and financial situation, with free access to education (Kansanen \& Meri, 2006). Education is regarded as a fundamental right for all citizens and is free at all levels, from primary to higher education.

Moves towards inclusion have prompted changes in the formation of education policies, schooling structures and pedagogical practice. The shift from "integration" towards a notion of "inclusion" where everyone is considered normal has been supported by United Nations policies, such as the Salamanca Statement on Principles, Policy and Practice in Special Needs Education (UNESCO, 1994). The concept of inclusion in an educational context can nowadays be understood as providing effective and tailored learning opportunities for every child, not only children with certain disabilities (United Nations, 2006). According to Konza (2008), this development is situated within a broad social justice discourse, which argues that equality for all must include access for all children to their local school. In recent decades, there has been an increasing trend to educate more pupils with disabilities in general education classroom settings, including physical education (PE) classes (Vickerman $\&$ Coates, 2009). However, the inclusion of students with disabilities presents significant challenges to PE instructors who must attempt to meet the diverse needs of students with and without disabilities (Overton, Wrench \& Garrett, 2016; Simpson \& Mandich, 2012). Despite the expanding international support for the concept of inclusion, the meaning and implementation of inclusive practices in PE vary in different countries (Haegele et al., 2017). Haegele et al. (2017) explored current inclusive PE practices in different countries such as Brazil, Japan, South Korea, Puerto Rico and the United States. The authors identified strategies that are effective in promoting the physical activity of children and adolescents with special needs such as cultural competence, environmental adaptations and curricular modifications. 
Although not evaluated in the PISA studies, PE has been an institution in Finnish schools since the mid19th century and has been a mandated subject content in Finnish basic education (Yli-Piipari, 2014). The research on inclusive education tended to focus on identifying factors that impact teachers' attitudes towards inclusion, rather than on pedagogical practices. The type and severity of students' disabilities have been identified as playing significant roles in forming teachers' attitudes towards the inclusion of students in PE (Morley, Bailey, Tan, \& Cooke, 2005; Obrusnikova, 2008). PE teachers show negative attitudes towards the inclusion of children with behavioural or emotional disorders (Obrusnikova, 2008; Rizzo \& Vispoel, 1991). On the other hand, PE teachers' attitudes towards pupils with learning disabilities are often favourable (Meegan \& MacPhail, 2006; Obrusnikova, 2008; Rizzo \& Vispoel, 1991). Children with disabilities were often excluded from the class's sports activities because the curriculum was dominated by competitive activities with an emphasis on performance and technical skills (Smith \& Green, 2004; Morley et al., 2005). These studies showed that the curriculum contents seemed to have reduced the opportunities for students with disabilities to participate in the same activities as their peers without disabilities (Tant \& Watelein, 2016). Moreover, previous research explored that certain factors - for instance, the availability and collaboration with APE specialists (Heikinaro-Johansson \& Sherrill, 1994; Lienert, Sherrill \& Myers, 2001) - have an influence on teaching effectiveness in PE. Few researchers concentrated on pedagogical practices that facilitate the inclusion of students with special needs in PE. That said Overton et al. (2016) conducted qualitative research in Australia that focused on pedagogies for inclusion of junior primary students with disabilities in PE. In order to fill this gap, the main purpose of this study is to reveal pedagogical practices of PE teachers and didactic choices that they find necessary to ensure the participation of children with disabilities in PE classes.

In this paper, I will first give a brief overview of the role of PE and inclusion in a Finnish context. I will then draw upon the theoretical framework that was used for the conceptualization of the data themes. Within a social justice framework, teachers' pedagogies were considered as attempts to achieve socially equal outcomes for their pupils (Lingard \& Mills, 2007; Overton et al., 2016). Through social justice lens, Goodwin (2017) challenges educators to reflect on their professional practice, and the construction and discourse of disability that form the basis for their pedagogical practice.

I will then describe the research design and procedure, data collection and analysis. The main research question explored in this study was: what are teacher's pedagogical and didactic strategies for dealing with diversity (including students with disabilities) in their PE classes? Finally, data will be presented and discussed through the themes of pedagogical practices, creating supportive learning environments and teaching competence.

\section{PE in Finland}

\section{Health as a central theme}

In Finland, PE has two main goals: to guide the pupils in adopting a physically active lifestyle, and to educate them through physical activities (Finnish National Board of Education, 2016). The focus of PE lies in the development of basic and specific motor skills during different seasons and in versatile learning environments. The intent of the instruction is to promote their pupils' competence regarding health, wellbeing and safety. In Finland, the PE subject is based on a health concept that remains "one of the main pillars for legitimizing PE" (Annerstedt, 2008). With the implementation of the new National Core Curriculum in 2016, schools are required to implement a national fitness assessment and feedback program (called MOVE) to evaluate students' fitness levels and to motivate students to participate in health-enhancing physical activities (Yli-Piipari, 2014). The Finnish PE curriculum has been divided into physical and health education, both taught as separate subjects. However, both subjects are closely linked to each other in terms of goals and content. While the focus of PE lies in the development of a wide variety of motor skills, health education is based on a multidisciplinary foundation of knowledge. The activities in Finnish PE are closely connected to achieving lifelong participation in physical activity through joy in movement, social acceptance and knowledge (Richter, 2007; Annerstedt, 2008).

\section{Teaching content and assessment}

According to Annerstedt (2008), outdoor activities have always played an important role in Scandinavian society in general, and especially in PE. Some sport activities are mentioned much more in the Finnish context than in other Nordic countries. For instance, floor-ball and ice-hockey are very popular sports in Finland (Heikinaro-Johansson \& Telama, 2005). 
Pesäpallo (Finnish baseball) is a common team game at all school levels and considered a national sport in Finland (Annerstedt, 2008). Although ball games seem to dominate the teaching content in Finland (see Table 1), the national curriculum recommends that PE should consist of a broad range of different physical activities. It includes many activities that focus more on joy in movement and a physically active lifestyle than on competition and performance. The most common activities performed by comprehensive school students in Finland are team sports. Table 1 provides further details on teaching content.

Table 1

Most common activities in PE programs in Finland (Heikinaro-Johansson \& Telama, 2005, 261)

\begin{tabular}{ll}
\hline $\begin{array}{l}\text { Comprehensive Schools } \\
\text { (Grades 1-6) }\end{array}$ & $\begin{array}{l}\text { Comprehensive Schools } \\
\text { (Grades 7-9) }\end{array}$ \\
\hline Ice Skating & Finnish Baseball (Pesäpallo) \\
Finnish Baseball (Pesäpallo) & Basketball \\
Play and Games & Track and Field \\
Football & Ice Hockey \\
Track and Field & Floor Hockey (Floor-Ball) \\
Floor Hockey (Floor-Ball) & Volleyball \\
Basketball & Orienteering \\
Gymnastics & Football \\
Volleyball & Fitness Training \\
Apparatus Gymnastics & Apparatus Gymnastics \\
\hline
\end{tabular}

The curriculum highlights the importance of the students' individual learning process in terms of assessing student performance. The assessment criteria for PE in grades 1-9 are related to three key content areas: physical functional capacity, social functional capacity and psychological functional capacity. These subject-specific competencies form a framework for more detailed objectives that are assessed by observing the pupil's actions and work. According to the national curriculum, the pupils' personal strengths and development needs are taken into account and supported in the feedback and assessment (Finnish National Board of Education, 2016). Some authors claim that there is a gap between what the curriculum indicates and what actually happens in practice, at least in Swedish PE (Annerstedt, 2008; Larsson \& Meckbach, 2007).

\section{Gender Aspects}

In Finland, schools have the option to organize $\mathrm{PE}$ in either coeducation or single-gender groups.
In elementary school grades, girls and boys typically participate in coeducational PE, whereas in middle school grades, single-gender classes are the norm (Yli-Piipari, 2014). The persistence of gender segregation and hierarchy in PE stems from educational policies as well as from the position of sport in Finnish culture (Berg, 2006). Several studies have shown that coeducation in PE disadvantages girls because of its traditional masculine form (Berg \& Lahelma, 2010). Berg and Lahelma (2010) revealed in their case study that gender segregation is still a current topic in Finnish PE. In the study, some teachers argued against co-educational groups in games during PE lessons because "boys played rougher and with greater competence. A male teacher occasionally included some girls in boys' games, but only girls who 'get along with the boys', that is, girls who played in a sports club in their leisure time" (Berg \& Lahelma, 2010).

\section{Students with special needs in PE}

The results of the study by Pirttimaa, Kokko, Räty, Pesonen and Ojala (2015) indicated that while physical integration in Finnish comprehensive schools has increased, individual integration into the fulltime mainstream classroom occurs only seldom. The answers of school staff (mainly teachers) revealed that partial integration was the most popular option $(45.8 \%)$ among the respondents. $36.3 \%$ of those who were interviewed indicated that students with severe disabilities should mainly be taught in special education groups (Pirttimaa et al., 2015). Almost half of the respondents $(46.6 \%)$ indicated that $\mathrm{PE}$ is the most suitable subject in which to include children with more severe disabilities in mainstream classes.

However, little has been investigated concerning the physical integration of pupils with special needs in PE classes in Finland. A study by Heikinaro-Johansson \& Sherrill (1994) indicates that $93 \%$ of secondary school PE specialists and 76\% of classroom teachers claim that they have children with special needs in their PE classes. Data were collected based on a survey of 138 secondary school PE teachers and 169 elementary classroom teachers in central Finland. As students with special needs are mainly integrated into mainstream schools nowadays, the figures may even be higher.

Factors based on APE training or experience with teaching students with disabilities can influence teachers' attitudes either positively and directly, or indirectly by contributing to the teacher's feelings of competence (Tant \& Watelain, 2016). Although training of APE is considered important, several authors 
showed the inefficiency of some programs that were too heavily based on theory (Vickerman \& Coates, 2009). Several APE training programs did not allow teachers to develop a truly inclusive classroom environment for students with disabilities. Teachers consistently considered practical training with a focus on didactic strategies and pedagogical adaptations as the most efficient way to acquire inclusive strategies, as well as frequent knowledge exchanges between and among professionals (Lieberman, Houston-Wilson, \& Kozub, 2002; Tant \& Watelain, 2016).

\section{Conceptual framework}

\section{Social justice and Honneth's theory of recognition}

Axel Honneth's theory of recognition represents an interdisciplinary approach, which includes an ethical perspective of relevance to sports, games and play. According to Andersen (2015), recognition is fundamental both for the self-realization of individuals and for maintaining a just society. To my knowledge, Honneth's conceptual framework has not been applied in analyses of pedagogical practices in PE. However, a similar approach was used by Overton et al. (2016) in examining the pedagogies and attitudes of PE teachers in teaching junior primary students with disabilities. By drawing on the concept of social justice, the authors referred to three interrelated areas identified by Fraser (2010): recognition, redistribution and representation. According to the study by Overton et al. (2016), the participants were showing a strong sense that their students with disabilities had a fundamental right to participate in mainstream PE lessons. In contrast to Fraser, Honneth claims that a sufficiently differentiated theory of recognition can be regarded as a key concept, which structures normative life of society as a whole (Ohlström, Solinas, \& Voirol, 2011). Within a social justice framework, Honneth's theory of recognition may contribute to new perspectives on physical activities by articulating its values and identifying violations or disrespect (Andersen, 2015).

Honneth (1995) identifies three different spheres of recognition in our modern society: love, rights and solidarity. Love as an emotional dimension of justice is characterized by social relations such as friendships and family relations. It is restricted to a limited number of partners in interaction. From a moral-philosophical point of view, Honneth (1995) claims that people can only form a positive evaluative self-relation if they participate in social relations that require an attitude of reciprocal recognition. According to Andersen (2015), love can be inherent in sport both as a form of reciprocal recognition between athletes and as play. From the children's perspective it involves having friends and feeling like a legitimate participant in PE (Spencer-Cavaliere \& Watkinson, 2010).

Rights as another sphere of recognition refers to the personal experience of having legal recognition. Thus allows us to see our own actions as the universally respected expression of our own autonomy (Honneth, 1995). In terms of inclusive education, legal respect has developed historically through a struggle for recognition. In Finland, the gradual shift to a comprehensive school system following the Comprehensive School Act of 1970 was guided by the principles of "equality and equity in educational opportunities" (Kivinen \& Kivirauma, 1989). In 1998, the new Basic Education Act focused on equal rights to education for all, no matter the school or municipality (Ekstam, Linnanmäki, \& Aunio, 2015). In practice, these legal changes mean that every child - including those with a disability - has the right to attend a local comprehensive school (Graham \& Jahnukainen, 2011). In line with UN sustainable development goals (goal 4, "inclusive and equitable quality education"), Finnish basic education is nowadays guided by the inclusion principle (United Nations, 2015): The accessibility of education must be ensured on school level by offering supportive learning environments for all pupils (Finnish National Board of Education, 2016).

The potential for recognition in the form of solidarity refers to a situation in which most members of society can be given social appraisal for their skills and abilities and thereby establish their self-esteem (Andersen, 2015; Honneth, 1995). Thus, social esteem refers to individual skills that are of value of the society and should contribute to the realization of social goals. In relation to $\mathrm{PE}$, it is often necessary to possess certain basic motor skills to be a member of any sports community. Individuals who lack movement competence are at greater risk of rejection by peers and social isolation, which may be particularly challenging for children with disabilities (Obrusnikova, Block, \& Dillon, 2010; Spencer-Cavaliere \& Watkinson, 2010).

According to Giese and Ruin (2018), PE teachers have a general tendency to instrumentalize the body. PE teachers with this attitude tend to focus on deficits when dealing with persons whose bodies deviate from the norm, which can be regarded as an obstacle for equal participation for students with disabilities in PE (Giese \& Ruin, 2018). It is therefore important that teachers recognize and value the abilities and voices (Bredahl, 2013; Lingard \& Keddie 2013) 
of students with special needs. Engaging in a process of negotiation with the learner can help teachers meet the students' individual needs and abilities (Fitzgerald \& Jobling, 2004) and foster solidarity among the children.

\section{Methods}

\section{Research procedure and Description of participants} This study investigates teachers' points of view regarding the changes and differentiations in their teaching content and didactic choices to ensure the participation of children with disabilities in their class. Based on the research design used by Overton et al. (2016), a case study was conducted with the intention of developing understandings about inclusive pedagogies for PE in Finnish Basic Education (grades 1-9). Participants were provided with information letters about the research project and signed consent was obtained before the research. Participation was voluntary, and withdrawal at any stage was possible. Participants were three subject teachers in PE (all male), four special education teachers (all female) and one female class teacher who met the key requirement of having previous experience in teaching PE to students with disabilities.

A purposeful sampling approach using the strategy of criterion sampling was used to recruit the participants (Patton, 2002). Participants were selected based on the assumption that they possess knowledge and experience with the phenomenon of interest, and thus are able to provide information with a certain depth and breadth (Cresswell \& Plano Clark, 2011). A focus on different practitioners (subject teacher, class teacher and special education teacher) aimed to capture the insights and experiences from various perspectives. Their ages ranged from 30 to 60 , and their pedagogical work experience ranged from 4 to over 30 years. Data collection took place in three public comprehensive schools and one special school in the Metropolitan area of Helsinki. Comprehensive schools in Finland are traditionally divided into elementary school grades 1-6 and middle school grades 7-9 (Yli-Piipari, 2014). Pseudonyms were allocated and steps taken to prevent the identification of personal information or school locations. Additional demographic information is presented in Table 2.

Matti is an early-career teacher with less than five years of experience in teaching PE in a centre for learning and consulting. The centre consists of a consulting unit and a school unit. The consulting unit organises national and local school-specific training courses financed by the Finnish National Board of Education and are free of charge for the participants. In the school unit, mainly students with multiple disabilities are taught in special groups on a permanent or temporary basis. Two participants (Vilho and Tuomas) have more than 20 years of teaching experience as PE teachers at the secondary level (7th-9th grade) in two different comprehensive schools. At their schools, students with special needs are mainly integrated into mainstream PE classes. Both teachers also teach health education as a separate subject. The fourth participant (Iina) teaches PE in primary school classes (1st-6th grade). This teacher teaches students with visual and physical disabilities in mainstream PE lessons.

All special education teachers had a pedagogical diploma in special needs education, whereas three had a double qualification (class teacher and special teacher education). Suvi, Janika and Satu need to have a double qualification (class teacher and special teacher) as they are providing special support as so called "special class teacher". For Julia a special teacher qualification is sufficient, as she teaches children in part-time special education on the other support levels, called general and intensified support (Ström \& Hannus-Gullmets, 2015). Julia is an early career special education teacher with less than five years of work experience. She is mainly teaching individual students and small groups of children with general support in part-time special education or as co-teacher in mainstream education.

Suvi and Janika have more than 10 years of teaching experience as special class teachers on primary (1st-6th grade) and secondary level (7th-9th grade) in two different comprehensive schools. At their schools, students with special needs are partly integrated into mainstream classes, and partly taught in special classes. Satu teaches within a special school as a special class teacher (6th grade). She mainly teaches one group of students with a wide range of learning difficulties and has almost 30 years of pedagogical work experience as a special class teacher.

\section{Design and Data Collection}

The investigation used a qualitative approach. Qualitative data was collected through semi-structured interviews, field notes and participant observation (Lüders, 2009; Mayring 2010). The interview questions were designed so that the teachers could freely describe the aspects they consider important in their own pedagogical practice. The teachers were encouraged to explain their answers and share their experiences via follow-up questions. The interviews lasted 40 minutes on average and were recorded and 
Table 2

Description of Participants $(n=8)$

\begin{tabular}{lcclcl}
\hline Pseudonym & Male/Female & $\begin{array}{c}\text { Age } \\
\text { (years) }\end{array}$ & School, class level & $\begin{array}{c}\text { Teaching } \\
\text { experience } \\
\text { (years) }\end{array}$ & Description \\
\hline Matti & Male & 30 & Special school, grades 1-9 & 4 & subject teacher, PE \\
Vilho & Male & 48 & Comprehensive school, grades 7-9 & 21 & subject teacher, PE \\
Tuomas & Male & 51 & Comprehensive school, grades 7-9 & 22 & subject teacher, PE \\
Iina & Female & 40 & Comprehensive school, grades 1-6 & 9 & class teacher \\
Julia & Female & 32 & Comprehensive school, grades 1-6 & 4 & special education teacher \\
Suvi & Female & 44 & Comprehensive school, grades 1-9 & 13 & special class teacher \\
Janika & Female & 41 & Comprehensive school, grades 1-9 & 11 & special class teacher \\
Satu & Female & 60 & Special school, grades 1-6 & 29 & special class teacher \\
\hline
\end{tabular}

transcribed verbatim. Sections of quotes consisting of such things as ' $\mathrm{hmm}$ ' and repeated words have been removed for the sake of clarify. The procedures followed the guidelines of the national research ethics committee (Academy of Finland, 2003). These guidelines include procedures for handling misconduct and fraud in science, which is primarily the responsibility of each individual researcher.

The interview questions covered four different categories related to the teacher's attitudes and experiences concerning inclusion, teaching in the field of PE, the curriculum and the school environment. The study was guided by the following question: What are teacher's pedagogical and didactic strategies for dealing with diversity (including students with disabilities) in their PE classes?

After each interview, the interviewer recorded reflective field notes. The field notes contained quotations and the researcher's individual feelings, experiences and insights (Patton, 2002). Descriptive information (time, date and location) concerning the interview setting were noted. The field notes served as a reminder of the interview during the process of data analysis, and verification of data interpretations (Patton, 2002).

Participant observations were conducted to expand on the data gathered from the semi-structured interviews. Each participant was observed teaching several PE lessons to classes that included students with disabilities. A guideline with predetermined categories (Lüders, 2009) was used to conduct the observations in a more structured manner. The categories focused on teaching style, rules and regulations, environments and equipment (Australian Sports Commission, 2006). Throughout the observation process, participant's actions were documented. Overall, interviews and observations provided a holistic view of teachers' practices and didactic choices in relation to including students with disabilities in PE.

\section{Cross-language research}

A language barrier existed between myself and the participants of the study, as I was not familiar with the local language (Finnish). The research became a cross-language qualitative study with unique challenges related to language (Temple \& Young, 2004). Most of the interviewees felt comfortable in using English in the interviews. The choice of language simply appeared natural to the researcher in the given context, as interviewer and interviewee were both non-native speakers of English (Welch \& Piekkari, 2006).

A third person in the role of interpreter was not involved in the data collection process as the language proficiency levels of the interviewees were sufficient to express their thoughts and opinions. Often, accuracy and authenticity are concerns for those researchers who had used interpreters, since original meanings can easily be lost in the act of translation (Welch \& Piekkari, 2006). Inappropriate use of translators or interpreters can even threaten the trustworthiness of cross-language qualitative research.

\section{Data Analysis}

A second reader, a native speaker of English, was involved in transcribing the interviews in the original language. Interviews were initially transcribed by the researcher and checked by the second reader. Differences were discussed, and changes were made until consensus was reached. This process led to a double analysis: transcripts were analysed from the perspective of a native speaker of English regarding linguistic issues, as well as from the perspective of the researcher, who questioned meanings and expressions related to the questions that guided the research. 
The transcription of the interviews resulted in 112 pages of data. Content analysis served as the basis for the data analysis. The interviews were analysed by adopting the inductive content analysis method (Mayring, 2010). The main principle of inductive category development is that the categories are as near as possible to the material, the material is worked through, and categories are tentative and deduced step-by-step.

The analysis consisted of two different phases. In the first phase, I read the interviews through several times in order to understand the "big picture". The second phase focused on discovering responses that highlighted important messages or findings using inductive content analysis, in which the qualitative data were analysed without theoretical assumptions (Mayring, 2010). A line-by-line analysis was carried out in which words, sentences, and paragraphs were examined and grouped by topic. This method was used to explore the similarities and differences regarding pedagogical practices, the school environment, and teachers' attitudes towards inclusion via labelling and coding of the data.

The analysis involved three steps: data reduction, grouping and conceptualisation (Flick, 2009). First, all text segments that referred to the teacher's pedagogical and didactic choices for dealing with diversity were identified and coded into the same category. In the second step (grouping) the selected descriptions were subsumed into three different groups, step by step. Following the research questions, these groups were conceptualised as categories, which were carefully founded and revised within the process of analysis (step 3: conceptualisation). Once all the data had been grouped, themes were developed until saturation was reached and no new data were emerging. The broad themes that emerged from the data analysis are: pedagogical practices, creating supportive learning environments and teaching competence. The participant's quotes are used to illuminate discussions about discourses drawn on and to make connections between previous research.

\section{Trustworthiness}

The trustworthiness of this study was achieved in various ways. The researcher had experience in leading multi-professional teams and working with children with and without disabilities in various physical activity programs for seven years. This included the roles of teacher and researcher in Germany and Finland. These professional experiences facilitated the researcher's ability to understand the various activity contexts teachers referred to in the interviews. Data collection took place during a one-year stay as a visiting doctoral student and researcher in Finland. Combining explicit and tacit forms of knowledge was important in order to decide on what direction the research project will head. Accessing tacit knowledge takes significant time in the field. The longer researchers are present, the more likely they are to notice culture's values (Tracy, 2010).

Three sources of data (interviews, reflective field notes and participant observation) were collected to establish credibility. In addition to triangulation of the sources of data, member reflections were used as an opportunity for collaboration and reflexive elaboration (Tracy, 2010). The researcher e-mailed the interview transcripts to the respective participants (members), which ensured trustworthiness of the data (Meho, 2006). The reflections of the interviewees also helped the researcher to learn whether the participants find the research comprehendible and provided additional data for deeper analyses. Providing opportunities for questions and feedback were important as the interviews were conducted in English, which is not the native language for participants and researcher.

Dependability and confirmability of the findings were established using a second reader who was involved in the process of transcription. The second reader was a native speaker of English and had experience in qualitative data analysis. Reflexive reading was also carried out to clarify researchers' views, during the steps of data evaluation and interpretation. Reflections were noted in memos and became legitimate additional data through the process of reflexivity (Cohen, Marion, \& Morrison 2007). In addition, observational data was used to clarify understanding about teachers' interactions, pedagogical decisions and responses in the interviews. Triangulation involved the use of multiple data sources including data from interview transcripts, participant observation and reflective field notes. Credibility was achieved by triangulating the data between the participants by reading each participant's data set separately and then comparing it against the data set of other participants (Blagrave, 2017).

\section{Results}

\section{Pedagogical practices}

A previous study by Pirttimaa et al. (2015) revealed that teachers regard PE as the most suitable subject for the inclusion of children with special needs. However, sports activities in general do not necessarily have 
positive effects on including students with special needs. According to Thiele (2009) practical experiences in PE in inclusive settings indicate that sports activities can only show inclusive potential in certain adapted sports or niches.

All participants indicated that they adapted games and activities so that everybody in the class can participate in the sports activities. Iina mentioned the modification of rules and equipment to include students with disabilities:

In PE it is possible to change the rules and the materials of the games, so that everybody can participate. In floorball, for example, you can use special rules to make the game easier. (...) Adaptions are important because every child is at a different level. (Iina)

Vilho also refers to the adaption of teaching materials commenting: "Of course there are different balls that we use in teaching ball games. There are some huge balls in volleyball that you can use to make a game easier for everyone."

Drawing on social justice discourses of recognition, Iina and Vilho show that equipment and rules could easily be adapted to accommodate specific needs of their pupils. The following comment by Tuomas describes the possibility of differentiation within the PE class by using different exercises that are suitable for some students:

There are so many ways how to deal with the differences. You can use different exercises for one group, other exercises for the other group. Another option is to modify rules of the games or use different balls and equipment. (Tuomas)

This comment reveals Tuomas' willingness to provide access to educational resources and recognition of the specific needs of his students. Inclusive practices may also require differentiated learning experiences as suggested in former studies (Overton et al., 2016). In terms of social justice, it becomes evident that physical activities should be planned for all, regardless of their individual condition.

Another subject teacher of PE (Matti) refers to certain sport "niches" that can be used in an inclusive teaching setting with little modifications:

There are certain sports like rugby or kin-ball that can be mainly used without any adaptions. In rugby, the weak students became suddenly better than the stronger ones. Because rugby is so different than other sports. (Matti)
This comment from Matti provides further evidence of drawing on social justice discourses of recognition by choosing and modifying sport activities in a way that all students could experience success. Matti also mentioned games that are typically known as adapted sports for disabled people. According to this teacher, blind football can be an exciting experience for the whole class that usually has a positive influence on social relationships between and among the students. Blind football is played with a ball with bells inside to accommodate the needs of blind and visually impaired children.

According to my teaching observations, PE lessons at the primary school level (1st-6th grade) contained a wide variety of different games. Traditional games like floorball and Pesäpallo (Finnish Baseball) were adapted to the needs of the students through modification of the rules and number of players. Apart from that, several teachers encouraged children to communicate with each other and to use different equipment. In the next theme, the paper will focus on how the participants interpreted and created supportive learning environments.

\section{Creating supportive learning environments}

The Finnish national curriculum (2016) highlights the importance of providing a safe learning environment in relation to mental health and wellbeing. According to the Finnish National Board of Education (2016), pupils should actively take part in developing engaging learning environments for all learners.

Several participants mentioned the importance of supportive learning environments for students with special needs. Julia, for instance, emphasised the need for teaching students with certain disabilities in separate groups:

I try to choose students that could do the same kind of things, who have the same kind of problems. We have many students who really need to have a very quiet and peaceful environment. And then there are others who are quite noisy. It makes no sense to mix them. (Julia)

Julia identified noise levels as an environmental aspect that has an impact on inclusive teaching. Consequently, she divided her PE class into small groups to complete activities in different areas of the sports hall thus reducing noise levels for her students with autism.

Recognition of students' capabilities and individual needs seem to be extremely important conditions to build up safe learning environments and achieve 
equal opportunities for all students. Julia and Suvi also stressed the importance of encouragement and positive feedback. Julia reported that, "there is a lot of empowering work that I do with them to support their self-esteem. I think this is the most important thing. Find their strengths and then start to build on those."

Previous research has indicated that encouragement and differentiated learning experiences have a positive impact on creating a supportive learning environment in PE (Beamish \& Saggers, 2014). Both, Julia and Suvi, draw on social justice discourses of recognition in showing understandings of the pupil's ability and willingness to build on their skills and capabilities.

Tuomas also shows a positive attitude towards the different needs of his pupils:

I concentrate on every student as an individual because they are so different in their way of learning and behaviour (...). It is very important to accept the diversity. It is helpful to have a positive attitude towards the different needs of the students, even though sometimes it is quite difficult to do that in practice. (Tuomas)

A recent study by Spencer-Cavaliere and Watkinson (2010) showed that children referred to the role of adults as facilitator in offering supportive learning environments. However, the children's peers seemed to play the most significant role in feeling included in sports and games. By drawing on a socioecological model, Blagrave (2017) has been able to show that peers and family members can have both a positive influence and a negative influence from the perspective of children with autism spectrum disorders. By analysing cases of disrespect (Honneth, 1995), it seems that the notion of solidarity refers to appreciation and recognition of athletes' skills and abilities by their fellow players (Andersen, 2015). It thus becomes important that teachers discover ways to facilitate the participation of all students by supporting solidarity and cooperation among children (Obrusnikova et al., 2010).

Throughout the observation process, several participants attempted to strengthen the pupils' participation. Pedagogical practices included different forms of verbal encouragement and forms of differentiation of content and tasks in negotiation with the students. Teaching observations highlighted the didactic choices of setting up stations where students completed different activities during the same lesson according to their individual needs. In individual sports (e.g., fitness exercises), Vilho, Julia and Suvi tried to find suitable and meaningful exercises for students with special needs, while the more experienced learners could select exercises independently, according to their individual training plan. The pedagogical aspect of teaching also included "peer tutoring". In this case, another student served as a peer tutor to support a student with disabilities in his fitness exercises. In terms of social justice, "love" as one sphere of Honneth's theory of recognition refers to the physical closeness that one acquires by cooperating with each other in exercises and games, which can help to establish friendships.

\section{Teaching competence}

A study conducted by Paju, Räty, Pirttimaa and Kontu (2015) examined the factors that identify the school staff's ability to meet the needs of pupils' special needs in their daily teaching situations. The results indicate that teachers' qualifications are the main factor affecting their ability in this area. Engsig and Johnstone (2014) and Bredahl (2013) also pointed out teachers' lack of ability to include pupils with special needs stems from a lack of knowledge, competences, in-class support and consultative services. The integration of pupils with special needs and disabilities into regular schools requires that school staff demonstrate positive attitudes, knowledge and skills to respond to the individual needs of all children. If the teacher feels experienced in an inclusive classroom, this leads to a stronger sense of self-efficacy (Meijer \& Foster, 1988).

Although most of the participants showed a positive attitude towards their teacher education and their perceived teaching expertise, Julia complained that her studies did not prepare herself to work with children with more specific disabilities, such as blindness:

In theory I can do that but, of course, special education was just one year (...) and there is a little bit of everything, so after that to really work with blind persons, for example, I would need to have much more [courses]. (Julia)

Suvi refers to the possibility to consult a professional with expertise in this field:

I remember when I moved here, I was going to have a blind kid. Then they told me that they are going to send some educator from a blind school that is going to educate me how to work with this. Finally, the child did not come to my class. But anyways, this is how we handle the things. (Suvi)

Those PE teachers who felt they were competent in teaching students with disabilities also had 
more positive attitudes towards inclusion, as they regard it as a professional challenge (Block \& Rizzo, 1995; Obrusnikova, 2008; Rizzo \& Vispoel, 1991). On the other hand, a lack of perceived competence was considered a major obstacle to inclusion (Bredahl, 2013, Spencer-Cavaliere \& Watkinson, 2010). Several studies show the positive effects of APE training on teachers' attitudes towards the inclusion of students with disabilities (Block \& Rizzo, 1995; Obrusnikova, 2008). Satu, a special class teacher without specific APE training, shows a negative attitude towards teaching PE due to her perceived lack of teaching competence in this field:

I am not good in teaching physical education. Every year I say to my principal, please do not put me into these classes because I do not know how to teach (PE). My strengths are somewhere else. But due to certain things I teach my class in PE. (Satu)

Satu also showed negative attitudes towards the inclusion of children with behavioural or emotional disorders:

If a child only has physical impairments, I think that inclusion is excellent for those. But for some students who can't read, they can't concentrate, they fight, they scream, they are anxious, they are everything. You cannot put these children into a group of 30 students who are very clever. (Satu)

The type and severity of students' disabilities has been identified as significant factor in forming teachers' attitudes towards the inclusion of students with certain disabilities in mainstream classrooms (Morley et al. 2005; Obrusnikova 2008). In line with previous research, the comment by Satu shows that the type of disability, the class size and the lack of resources can be interpreted as an obstacle in inclusive teaching settings.

Satu draws on social justice discourses of recognition, founded on (dis-)respect for students' abilities and knowledge. Her comments reflect a negative attitude towards the inclusion of children in mainstream teaching setting due to individual (dis-)abilities focusing on the deficits. Appreciating the significance of pedagogical practices seems evident for equal learning experiences for all pupils. Julia, Suvi and Satu mentioned that they do not feel educated enough to deal with certain disabilities, such as blindness, in their own classroom setting. However, in case they have a child with certain disabilities in their class, they know that they can consult a professional with an expertise in this field.
Two subject teachers in PE, on the other hand, showed a positive attitude towards teaching APE due to their university training. Matti reports that, "if I think about my PE studies, it gives me an excellent basis on how to teach PE."

Tuomas explains that, "The [APA] studies prepared me quite well for work life. I did my Masters in Jyväskylä, where I learned how to adapt PE lessons to the individual needs of the kids." While Matti highlights the positive impact of the PE studies on his teaching competence, Tuomas also refers to the high quality of Finnish teacher education and the role of admission tests for teacher studies in general: "I would say teacher education in Finland is on a high level. I remember I had to study a lot to get accepted at the university."

Teacher education is one of the most desired study programs in Finland and the selective structure of teacher training is considered by several Finnish authors as one of the main reasons for the successful performance of Finland in the PISA studies (Sahlberg, 2011). Tuomas emphasised that APE teachers in Finland are held to high standards. The current APA curriculum of the University of Jyväskylä (2014) supports future teachers in planning and implementing class activities where students with disabilities are included. An emphasis lies on providing knowledge about each student's type of disability and environmental adaptations.

\section{Conclusion and Discussion}

This paper investigated different teachers' points of view regarding changes and differentiation in their teaching content and didactic choices that they find necessary to ensure the participation of children with disabilities in PE classes. By drawing on a social justice framework related to Honneth's theory of recognition, the purpose of the current study was to determine new perspectives on APE by identifying facilitators and possible barriers or disrespect in the participants' pedagogical practices. In relation to the question that guided the research, significant pedagogical practices included adapting equipment and modification of traditional sport games and activities (e.g., rules of the game, number of players) so that they suit the specific group.

Many approaches can serve as a guideline for didactic choices and the pedagogical aspects of teaching, such as the Australian approaches TREE \& CHANGE IT (Australian Sports Commission, 2006) or the Inclusion Spectrum Model (Black \& Stevenson, 2012). 
In addition, different effective instructional adaptations and strategies can help PE teachers build social relationships between children with and without disabilities:

- The implementation of "reverse inclusion" by using a sport usually reserved for people with disabilities, e.g. goalball (Black \& Stevenson, 2012; Grenier, 2006);

- Forms of cooperative learning (Grenier, 2006; Johnson \& Johnson, 1999); and

- Peer tutoring (Klavina \& Rodionova, 2016).

Within a social justice framework that links inclusion to human rights and social justice, the results of this study suggest that teachers' attitudes towards the inclusion of pupils with special needs have an influence on their pedagogy. Creating a supportive learning environment has been mentioned by several participants as the most important factor for teaching students with special needs in PE classes. In order to provide a safe and engaging learning environment, it is important for teachers to recognise the students' needs and abilities, and to collaborate with the children in developing engaging learning environments for all learners. Participants also mentioned forms of differentiation regarding teaching content and tasks by splitting up the class into smaller groups. The special class teachers considered it important to work with pupils with special needs individually or in small groups that are organized homogeneously. Those participants see themselves as experts for children with mainly learning difficulties and behavioural issues, and prefer to be responsible for this specific group of children. They regard it as necessary to provide certain students with a safe and supportive classroom environment in order to deal with the individual needs of the children.

Another important concern the participants had regarding inclusion involved the quality of their professional preparation for inclusion in PE. The special class teachers were showing a positive attitude towards their perceived teaching competence with students with learning problems and behavioural issues. Children with this kind of special needs built up the main target group in inclusive teaching settings. One participant, however, showed a negative attitude towards teaching PE due to her self-perceived lack of teaching competence. The findings concur with previous findings on the importance of the quality and consistency of professional training: Lieberman et al. (2002) suggest that APE training should focus more on the didactic strategies and pedagogical adaptations necessary to address challenges in a real classroom, and reduce the amount of instructional time spent on the theoretical aspects of disability. Two PE teachers, on the other hand, had a positive attitude towards teaching PE due to their university training in APE. However, the University of Jyväskylä is the only institution in Finland that offers a university-level study program in APE that leads to a MSc. degree. The profession is so popular that only $5 \%$ of applicants secure a place at the university (Heikinaro-Johansson \& Telama, 2005).

\section{Perspectives}

The results of this study confirm the need for additional training in APE and more effective cooperation between APE specialists and teachers with little teaching competence in this field (Koivumäki, 2014; Vickerman \& Coates, 2009). The frequency and quality of the exchanges between teachers and APE specialists could contribute to sharing knowledge about adapting physical activities to the needs of children with disabilities in practice. Inclusive education in PE also challenges teacher education. As inclusive practices are becoming more common in Finland, there is a need for teacher education that implements "inclusive" content based on consultation and cooperation with teachers and other professionals. Detailed examination of the prevalence of children with disabilities in general schools and its associations with physical activity by Ng, Rintala, Tynjälä, Villberg and Kannas (2014) and Ng et al. (2016) showed low amounts of physical activity among adolescents with disabilities in Finland. According to Ng et al. (2016), adolescents with disabilities need encouragement to be active daily, which can be achieved through sports club participation. However, sports clubs need to be prepared for including children and adolescents with disabilities in organized sport settings. The internet may be an effective setting for future courses in adapted physical activity, offering greater flexibility for the learner and instructor. In this context, $\mathrm{Ng}$, Rogers and Black (2017) investigated the utility of an online-based training as a way to train coaches and educators about best practice in the sport of sitting volleyball.

As suggested by Tant \& Watelain (2016), further research on disciplinary didactic and pedagogical training following a qualitative approach would be helpful for PE teachers to justify their educational choices. Multiple case studies with observations and interviews could add rich information for the analysis of teaching practices (Tant \& Watelain, 2016). 


\section{Limitations}

The findings in this report are subject to at least three limitations. First, given this small sample group, no analysis by gender was performed. Second, only one participant was a class teacher and as a result, no analysis of this profession was conducted. Third, as the researcher was not familiar with the local language (Finnish), the interviews were conducted in English, which is not the native language for participants and researcher. During the data analysis process, the language barrier became more significant. Some of the quotations in English were incomprehensible, requiring time-consuming clarifications about what the interviewees actually meant. Follow-up e-mail correspondence with the participants was utilized to supplement interview data when clarifications or further explanations were needed (Meho, 2006). E-mail correspondence was useful for returning the interview transcripts to the respective participants for verification.

\section{Declaration of Conflicting Interests}

The author declared no potential conflicts of interest with respect to the authorship and/or publication of this article.

\section{Acknowledgments}

The author thanks Prof. Jörg Bietz (Philipps University of Marburg, Germany) and Prof. Matti Meri (University of Helsinki, Finland) for their constructive suggestions, helpful feedback and support during the research process. Special thanks to Mirko Mihajlovic for proofreading the interview transcripts and his support in the review of the manuscript.

\section{References}

Academy of Finland (2003). Guidelines on research ethics. Helsinki: author.

Australian Sports Commission (2006). Sports ability activity cards. Retrieved from: http://www.ausport.gov.au/ participating/resources/coaches/tools/activity_cards

Andersen, W. (2015). Love, Rights, and Solidarity: Sports' Potential for Recognition. Physical Culture and Sport. Studies and Research, 68(1), 23-33.

Annerstedt, C. (2008). Physical Education in Scandinavia with a focus on Sweden: a comparative perspective. Physical Education \& Sport Pedagogy, 13(4), 303-318.

Beamish, W., \& Saggers, B. (2014). Strengthening Social and Emotional Learning in Children with Special Needs. In S. Garvis, \& D. Pendergast (Eds.). Health and Wellbeing in Children (pp. 303-315). Port Melbourne: Cambridge University Press.

Berg, P. (2006). What sets us in motion? - Physical exercise and sports hobbies in Finland 1981-2002. In M. Liikkanen, R. Hanifi, and U. Hannula (Eds.). Individual choices, permanency of cultures. Changes in leisure 1981-2002 (pp. 141-76). Helsinki: Statistics Finland.

Berg, P., \& Lahelma, E. (2010). Gendering processes in the field of physical education. Gender and Education, 22(1), 31-46.

Black, K., \& Stevenson, P. (2012). Information and advice. The Inclusion Spectrum incorporating STEP. Retrieved from http://www.englandathletics.org/disability-athletics/ resources.

Block, M. E., \& Rizzo, T. L. (1995). Attitudes and attributes of GPE teachers associated with teaching individuals with severe and profound disabilities. Journal of the Association for Persons with Severe Handicaps, 20(1), 80-87.

Blagrave, J. (2017). Experiences of children with autism spectrum disorders in adapted physical education. European Journal of Adapted Physical Activity, 10(1), 17-27.

Bredahl, A-M. (2013). Sitting and watching the others being active: The experienced difficulties in PE when having a disability. Adapted Physical Activity Quarterly, 30, 40-58.

Cohen, L., Manion, L., \& Morrison, K. (2007). Research Methods in Education (6th ed). New York: Routledge.

Cresswell, J. W., \& Plano Clark, V. L. (2011). Designing and conducting mixed method research (3rd ed.). Thousand Oaks, CA: Sage.

Ekstam, U., Linnanmäki, K., \& Aunio, P. (2015). Educational support for low-performing students in mathematics: the three-tier support model in Finnish lower secondary schools. European Journal of Special Needs Education, 30(1), 75-92.

Engsig, T., \& Johnstone, J. (2014). "Is there Something Rotten in the State of Denmark? The Paradoxical Policies of Inclusive Education - Lesson from Denmark." International Journal of Inclusive Education 19(5), 1-18.

Finnish National Board of Education. (2016). National Core Curriculum for Basic Education 2014. National core curriculum for basic education intended for pupils in compulsory education. Helsinki: Finnish National Board of Education.

Fitzgerald, H., \& Jobling, A. (2004). Student-Centred Research: Working with Disabled Students. In J. Wright, D. Macdonald, \& L. Burrows (eds.), Critical Inquiry and Problem-Solving in Physical Education (pp. 74-92). London: Routledge

Flick, U. (2009). An introduction to qualitative research (4th ed.). London: Sage.

Fraser, N. (2010). Scales of Justice: Reimagining Political Space in a Globalising World. New York: Columbia University Press.

Giese, M., \& Ruin, S. (2018). Forgotten bodies - an examination of physical education from the perspective of ableism. Sport in Society, 21(1), 152-165. doi: 10.1080/17430437.2016.1225857

Goodwin, D. L. (2017). Reflections on Professional Practice in Adapted Physical Activity Through a Social Justice Lens. In A. J. S. Morin, C. Maïano, D. Tracey \& R. G. Craven (Eds.), Inclusive Physical Activities: International Perspectives (pp. 271-286). Charlotte, NC: Information Age Press.

Graham, L. J., \& Jahnukainen, M. (2011). Wherefore Art Thou, Inclusion? Analysing the Development of Inclusive 
Education in New South Wales, Alberta and Finland. Journal of Education Policy, 26(2), 263-288.

Grenier, M. (2006). A social constructionist perspective of teaching and learning in inclusive physical education. Adapted Physical Activity Quarterly, 23(3), 245-260.

Haegele, J. A., Hersman, B., Hodge, S., Samalot-Rivera, A., Saito, M., Sato, T., \& Silva, A. (2017). Students with Disabilities in Brazil, Japan, South Korea, and the United States: Implications for Inclusion and Social Justice in Physical Education. In A. J. S. Morin, C. Maïano, D. Tracey \& R. G. Craven (Eds.), Inclusive Physical Activities: International Perspectives (pp. 287-308). Charlotte, NC: Information Age Press.

Heikinaro-Johansson, P., \& Sherrill, C. (1994). Integrating children with special needs in physical education: a school district assessment model from Finland. Adapted Physical Activity Quarterly, 11(1), 44-56.

Heikinaro-Johansson, P., \& Telama, R. (2005). Physical Education in Finland. In U. Pühse \& M. Gerber (Eds.), International comparison of physical education. Concepts, problems, prospects (pp. 250-271). Aachen: Meyer \& Meyer.

Honneth, A. (1995). The struggle for recognition: The moral grammar of social conflicts. (J. Anderson, Trans.). Cambridge: Polity Press.

Johnson, D. W., \& Johnson, R. T. (1999). Learning together and alone: Cooperation, competition, and individualization (4th ed.). Needham Heights, MA: Allyn \& Bacon.

Kansanen, P., \& Meri, M. (2006). Finland. In W. Hörner, H. Döbert, L.R. Reuter \& B. von Kopp (Eds.), The Education Systems of Europe (pp. 251-262). New York: Springer Verlag.

Kivinen, O., \& Kivirauma, J. (1989). Special education as a part of the school system and as a classification system: the case of Finland in the twentieth century. Scandinavian Journal of Educational Research, 33, 67-78.

Klavina, A., \& Rodionova, K. (2016). The Effect of Peer Tutoring in Physical Education for Middle School Students with Severe Disabilities. European Journal of Adapted Physical Activity, 8(2), 3-17.

Koivumäki, K. (2014). Basic facts about Adapted Physical Activity in Finland 2014. Ministry of Education. National Sports Council - Subcommittee for Adapted Physical Activity, Helsinki.

Konza, D. (2008). Inclusion of students with disabilities in new times: responding to the challenge. In P. Kell, W. Vialle, D. Konza, \& G. Vogl, (Eds.), Learning and the learner: exploring learning for new times (pp. 39-64). University of Wollongong.

Larsson, H., \& Meckbach, J. (2007). Idrottsdidaktiska utmaninsgar. Stockholm: Liber.

Lieberman, L. J., Houston-Wilson, C., \& Kozub, F. M. (2002). Perceived barriers to including students with visual impairments in general physical education. Adapted Physical Activity Quarterly, 19(3), 364-377.

Lienert, C., Sherrill, C., \& Myers, B. (2001). Physical educators' concerns about integrating children with disabilities: a cross-cultural comparison. Adapted Physical Activity Quarterly, 18(1), 1-17.

Lingard, B., \& Keddie, A. (2013). Redistribution, Recognition and Representation: Working Against Pedagogies of Indifference. Pedagogy, Culture and Society, 21(3), 427-447.
Lingard, B., \& Mills, M. (2007). Pedagogies Making a Difference: Issues of Social Justice and Inclusion. International Journal of Inclusive Education, 11(3), 233-244.

Lüders, C. (2009). Beobachten im Feld und Ethnographie. In U. Flick, E. von Kardoff \& I. Steinke (Eds.), Qualitative Forschung. Ein Handbuch (pp. 384-402). Reinbek: Rohwolt.

Mayring, P. (2010). Qualitative Inhaltsanalyse: Grundlagen und Techniken (11. Auflage). Weinheim: Beltz Verlag.

Meho, L. (2006). E-Mail Interviewing in Qualitative Research: A Methodological Discussion. Journal of the American society for information science and technology, 57(10), 1284-1295.

Meijer, C., \& Foster, S. (1988). The Effect of Teacher SelfEfficacy on Referral Chance. Journal of Special Education 22(3), 378-385.

Meegan, S., \& MacPhail, A. (2006). Irish physical educators' attitude toward teaching students with special educational needs. European Physical Education Review, 12(1), 75-97.

Morley, D., Bailey, R., Tan, J., \& Cooke, B. (2005). Inclusive physical education: teachers' views of including pupils with special educational needs and/or disabilities in physical education. European Physical Education Review, 11(1), 84-107.

Ng, K., Rintala, P., Tynjälä, J., Villberg, J., \& Kannas, L. (2014). Physical activity patterns of adolescents with long term illnesses or disabilities in Finnish general education. European Journal of Adapted Physical Activity, 7(1), 58-72.

Ng, K., Rintala, P., Välimaa, R., Tynjälä, J., Villberg, J., Kokko, S., \& Kannas, L. (2016). Daily physical activity in Finnish adolescents with long-term illnesses or disabilities: psychosocial associations with participation in sports club. Epidemiology Biostatistics and Public Health, 13(3), e11699. doi:10.2427/11699

Ng, K., Rogers, M., \& Black, K. (2017). The use of multimedia and the internet in providing global training opportunities for coaches in adapted sports: Case of Sitting Volleyball/VolleySLIDE. In A. J. S. Morin, C. Maïano, D. Tracey \& R. G. Craven (Eds.), Inclusive Physical Activities: International Perspectives (pp. 225-248). Charlotte, NC: Information Age Press.

Obrusnikova, I. (2008). Physical educators' beliefs about teaching children with disabilities. Perceptual and Motor Skills, 106, 637-644.

Obrusnikova, I., Block, M., \& Dillon, S. (2010): Children's beliefs toward cooperative playing with peers with disabilities in physical education. Adapted Physical Activity Quarterly, 27, 127-142.

Overton, H., Wrench, A., \& Garrett, R. (2016). Pedagogies for inclusion of junior primary students with disabilities in PE. Physical Education and Sport Pedagogy, 22(4), 414-426. doi: 10.1080/17408989.2016.1176134

Ohlström, M., Solinas, M., \& Voirol, O. (2011). On Nancy Fraser and Axel Honneth's Redistribution or Recognition? A Political-Philosophical Exchange. European Journal of Philosophy and Public Debate, 3(5), 205-221.

Paju, B., Räty, L., Pirttimaa, R., \& Kontu, E. (2015): The school staff's perception of their ability to teach special educational needs pupils in inclusive settings in Finland. International Journal of Inclusive Education, 20(8), 1-15.

Patton, M. Q. (2002). Qualitative research and evaluation methods (2nd ed.). Thousand Oaks, CA: Sage. 
Pirttimaa, R., Kokko, T., Räty, L.. Pesonen, H., \& Ojala, T. (2015). Intensive special educational needs and the development of inclusive practices in Finland. In F. Dovigo, C. Favella, F. Gasparini, A. Pietrocarlo, V. Rosso \& E. Zappell (Eds.). Special Education Needs and Inclusive practices: An International Perspective (pp. 149-153). Bergamo: University of Bergamo.

Richter, C. (2007). Concepts of physical education in Europe: movement, sport and health. International Journal of Physical Education, 44(3), 101-105.

Rizzo, T. L., \& Vispoel, W. P. (1991). Physical educators' attributes and attitudes toward teaching students with handicaps. Adapted Physical Activity Quarterly, 8(1), 4-11.

Sahlberg, P. (2011). Finnish Lessons: What can the world learn from educational change in Finland? New York: Teachers College Press.

Schraad-Tischler, D., \& Schiller, S. (2016). Social Justice in the EU - Index Report 2016. Social Inclusion Monitor Europe. Retrieved from: https://www.bertelsmannstiftung.de/filead$\mathrm{min} /$ files/BSt/Publikationen/GrauePublikationen/Studie NW_Social-Justice-Index_2016.pdf

Smith, A., \& Green, K. (2004). Including pupils with special educational needs in secondary school physical education: a sociological analysis of teachers' views. British Journal of Sociology of Education, 25(5), 593-607.

Simpson, K., \& Mandich, A. (2012). Creating Inclusive Physical Education Opportunities in Elementary Physical Education. Physical \& Health Education Journal, 77(4), 18-21.

Spencer-Cavaliere, N., \& Watkinson, E. J. (2010). Inclusion Understood from the Perspectives of Children with Disability. Adapted Physical Activity Quarterly, 27(4), 275-293.

Ström, K., \& Hannus-Gullmets, B. (2015). From special (class) teacher to special educator: The Finnish case. In D. L. Cameron, \& R. Thygesen (Eds.). Transitions in the field of special education: Theoretical perspectives and implications for practice (pp. 137-150). Münster: Waxmann.

Tant, M., \& Watelain, E. (2016). Forty years later, a systematic literature review on inclusion in physical education (19752015): A teacher perspective. Educational Research Review, 19(2016), 1-17.

Temple B., \& Young, A. (2004) Qualitative research and translation dilemmas. Qualitative Research, 4(2), 161-78.

Thiele, M. (2009). Bescheidenheit ist eine Zier: Chancen, Grenzen und Perspektiven sozialer Lernprozesse im gemeinsamen Sportunterricht. In M. Giese (Ed.), Sport- und Bewegungsunterricht mit Blinden und Sehbehinderten. Band 1: Theoretische Grundlagen - spezifische und adaptierte Sportarten (pp. 38-58). Aachen: Meyer \& Meyer Verlag.

Tracy, S. J. (2010). Qualitative Quality: Eight 'Big-Tent" Criteria for Excellent Qualitative Research. Qualitative Inquiry 16(10), 837-851.

UNESCO. (1994). The Salamanca Statement and Framework for Action on Special Needs Education. Adopted by the World Conference on Special Needs Education: Access and Quality, Salamanca, Spain, 7-10 June 1994. Paris: UNESCO.

United Nations. (2006). Convention on the Rights of Persons with Disabilities and Optional Protocol. Retrieved from: http://www.un.org/disabilities/documents/convention/ convoptprote.pdf

United Nations. (2015). Resolution adopted by the General Assembly on 25 September 2015. Transforming our world: the 2030 Agenda for Sustainable Development. Retrieved from http://www.un.org/ga/search/view_doc.asp?symbol=A/ RES/70/1\&Lang=E

University of Jyväskylä. (2014). Erityisliikunta. Liikuntatieteellisen Tiedekunnan Opinto-Opas [APA Study Program]. Retrieved from: https://www.jyu.fi/sport/opiskelu/opas3/ opinto-opas-2014-2017

Vickerman, P., \& Coates, J. K. (2009). Trainee and Recently Qualified Physical Education Teachers' Perspectives on Including Children with Special Educational Needs. Physical Education and Sport Pedagogy, 14(2), 137-153.

Welch, C., \& Piekkari, R. (2006). Cross Language Boundaries: Qualitative Interviewing in International Business. Management International Review, 46(4), 417-437.

Yli-Piipari, S. (2014). Physical Education Curriculum Reform in Finland. Quest, 66(4), 468-484.

\section{Corresponding author}

Christopher Mihajlovic

Email address | c.mihajlovic@jpss-fb.de 